\title{
Peran Bimbingan Keagamaan dalam Rehabilitasi Pecandu Narkoba
}

\author{
Lutfia Ulfah ${ }^{1}$, Witrin Noor Justiatini ${ }^{2}$ \\ ${ }^{1}$ Prodi bimbingan penyuluhan islam, Ciamis, STID Sirnarasa \\ lutfiaulfah09@gmail.com.
}

\begin{abstract}
ABSTRAK
Permasalahan narkotika telah membuat negara di dunia merasa resah dan khawatir. Proses rehabilitasi membutuhkan waktu lama, karena kecanduan narkoba sering disertai relapse. Sehingga, pecandu mengalami kesulitan dalam mengontrol perilakunya. Teori yang digunakan dalam penelitian ini adalah teori Rational Emotive Behavior Therapy dari Albert Ellis. Teori ini sesuai dengan tujuan dari adanya pelaksanaan bimbingan keagamaan dalam rehabilitasi yaitu bagaimana caranya agar dapat mengubah mindset klien, sehingga klien dapat berpikir dan berperilaku rasional. Pendekatan dalam penelitian ini yaitu deskriptif kualitatif, dikarenakan masalah yang diteliti perlu dijelaskan secara sistematis dan faktual dengan menggambarkan keadaan tempat penelitian. Simpulan dari penelitian ini adalah bimbingan keagamaan perlu dirancang, diorganisasi, dilaksanakan, diawasi dan dievaluasi dengan baik; dalam proses rehabilitasi dibutuhkan kerjasama dan dukungan penuh dari semua faktor; hasil dari bimbingan keagamaan adalah: mendapatkan ketenangan yang hakiki; adanya perubahan mindset, dan adanya perubahan perilaku.
\end{abstract}

Kata Kunci: Bimbingan Keagamaan; Rehabilitasi; Pecandu Narkoba

\section{ABSTRACT}

The problem of narcotics has made countries in the world feel restless and worried. The rehabilitation process takes a long time, because drug addiction is often accompanied by relapse. So, addicts have difficulty in controlling their behavior. The theory used in this study is the theory of Rational Emotive Behavior Therapy from Albert Ellis. This theory is in accordance with the purpose of the implementation of religious guidance in rehabilitation, namely how to change the

Diterima: Agustus 2021. Disetujui: September 2021. Dipublikasikan: September 2021 | 55 
Lutfia U. Witrin NJ

client's mindset, so that clients can think and behave rationally. The approach in this research is descriptive qualitative, because the problem under study needs to be explained systematically and factually by describing the state of the research place. The conclusion of this research is that religious guidance needs to be well designed, organized, implemented, monitored and evaluated; the rehabilitation process requires the full cooperation and support of all factors; the results of religious guidance are: gaining true serenity; a change in mindset; and a change in behavior.

Keywords: Religious Guidance; Rehabilitation; Drug addicts

\section{PENDAHULUAN}

Persoalan narkoba telah membuat negara di dunia merasa risau dan waswas akibat dalam setiap tahunnya problematika tentang narkoba ini semakin hari semakin ramai diperbincangkan, dikarenakan banyaknya manusia yang menjadi korban penyalahgunaan narkoba. Badan narkotika dunia atau United Nations Office on Drugs and Crime (UNODC) mencatat bahwa pada tahun 2017 setidaknya 5,5\% atau 271 juta jiwa dari jumlah keseluruhan masyarakat dunia dengan kisaran usia antara 15-64 tahun telah menggunakan narkoba (sumber : UNODC, World Drugs Report 2019). Selain itu, Badan Narkotika Nasional (BNN) juga menegaskan bahwasannya pemasalahan narkoba di Indonesia merupakan permasalahan urgen yang membutuhkan perhatian dan sikap kehati-hatian yang tinggi agar tercipta rasa kewaspadaan secara terus menerus dari seluruh komponen masyarakat Indonesia, baik dari masyarakat maupun aparat pemerintahnya.

Dari hasil eksplorasi dan investigasi yang dilakukan secara berkala oleh BNN setiap tiga tahun sekali, angka prevalensi terhadap narkotika mulai dari tahun 2011-2019 terjadi penurunan angka yang cukup signifikan. Dapat disimpulkan adanya penurunan angka prevalensi dari tahun 2011 sampai 2017. Hal ini memperlihatkan bukti nyata terkait upaya atau perjuangan BNN bersama instansi lainnya dalam menjalankan Pencegahan dan Pemberantasan Penyalahgunaan dan Peredaran Gelap Narkotika (P4GN) di Indonesia. Kendati demikian, kita tidak boleh lalai, 
Peran Bimbingan Keagamaan Dalam Rehabilitasi Pecandu Narkoba

harus siap siaga dan waspada karena kasus penyalahgunaan narkoba meningkat sejumlah $0,03 \%$ pada tahun 2019. Pertambahan kasus ini diakibatkan karena adanya kenaikan jumlah penyalahguna narkoba jenis baru yang pada tahun sebelumnya belum terdaftar di Lampiran UndangUndang Nomer 35 Tahun 2009 tentang Narkotika dan Permenkes Nomer 13 Tahun 2014.

Penyalahgunaan narkotika di Jawa Tengah terbilang cukup tinggi. Berdasarkan data dari Badan Narkotika Nasional (BNN) Provinsi Jawa Tengah untuk tahun 2019 tercatat mencapai 384 ribu warga. Menurut Kepala BNN Jawa Tengah Brigjen Pol Benny Gunawan bahwa Jawa Tengah masuk dalam peringkat lima tingkat Nasional dengan sebagian besar pecandu adalah generasi muda. Dengan angka prevalensi pecandu narkoba di Jawa Tengah adalah 1,16\% dari data nasional. Sedangkan berdasarkan data per tanggal 17 April 2020 untuk daerah kabupaten Purbalingga tercatat ada 87,5\% pengguna aktif laki-laki dan $12,5 \%$ perempuan. Jika dikelompokkan lagi secara lebih spesifik maka akan didapatkan data $12,5 \%$ adalah pelajar; $37,5 \%$ adalah pekerja; dan sisanya adalah populasi umum sebanyak $50 \%$. Data ini berdasarkan hasil wawancara per tahun 2020 dengan salah satu staf BNNK Purbalingga tentang pengguna narkoba yang tercatat dalam program rehabilitasi BNNK Purbalingga. Karena masih banyak kasus diluar sana yang belum diketahui.

Dalam dunia medis, beberapa jenis zat dalam narkoba sebenarnya memiliki fungsi utama untuk pengobatan. Akan tetapi, karena berbagai macam alasan mulai dari coba-coba, mengikuti tren dalam bergaya, ataupun pelampiasan untuk melupakan permasalahan dalam hidup. Oleh karena itu, kemudian narkoba disalahgunakan. Pemakaian narkoba yang dilakukan secara terus menerus akan menyebabkan ketergantungan atau kecanduan. Selanjutnya dari kecanduan inilah akan memicu dampak buruk terhadap gangguan psikis, fisik ataupun sosial. Dan apabila dilakukan secara kontinu dan berlanjut akan meningkatkan predikat penyalahguna narkoba menjadi pecandu narkoba. Secara sederhana pecandu narkoba merupakan penyalahguna narkoba yang telah 
Lutfia U. Witrin NJ

mengalami ketergantungan terhadap satu atau lebih jenis narkoba, baik secara psikis maupun fisik.

Agar tidak terjerumus kembali, maka dibutuhkan kontrol diri yang tinggi yang harus dimiliki oleh mantan pecandu narkoba. Karena dalam proses pemulihan untuk menghentikan kecanduan bukanlah hal yang sulit. Akan tetapi hal tersulitnya ialah mencegah agar jangan kembali mengalami relapse (kambuh). Kontrol diri adalah kemampuan dan keyakinan seseorang dalam mengarahkan perilakunya pada hal yang bersifat positif. (Aprilia Sukmadewi: 2010)

Kemampuan dalam mengendalikan kontrol diri menjadi salah satu faktor penting yang harus dimiliki supaya penyalahguna tidak terjerumus kembali yaitu dengan usaha pembentukan mental spiritual yang baik. Mental spiritual yang bertumbuh dengan baik akan berdampak pada kemampuan seseorang dalam beradaptasi dengan lingkungan, menumbuhkan kesadaran dalam diri yang tinggi, mampu menyelesaikan masalah yang menjadi beban dalam hidupnya, mampu memetik hikmah dari sebuah kegagalan, memiliki arah dan tujuan yang jelas dalam hidupnya, hingga pada akhirnya membuat seseorang memahami akan hakikat dalam hidupnya.

Untuk dapat memiliki mental spiritual yang baik, seseorang memerlukan bantuan seorang pembimbing dalam proses bimbingan keagamaan yang dilakukan secara kontinu. Sehingga melalui bimbingan keagamaan dapat menjadi jalan keluar dalam mengarahkan dan memberikan bantuan kepada pecandu narkoba dalam mengatasi berbagai permasalahan hidup agar selaras dengan norma agama dan sosial.

Salah satu lembaga rehabilitasi non medis yang berbasis bimbingan keagamaan dalam proses rehabilitasi bagi pecandu narkoba adalah Panti Rehabilitasi Narkoba Nurul Ichsan Al-Islami, Karangsari, Kecamatan Kalimanah, Kabupaten Purbalingga. Melalui keberadaan rehabilitasi berbasis bimbingan keagamaan ini semoga dapat memberikan harapan besar bagi para pecandu narkoba agar dapat kembali melanjutkan 
Peran Bimbingan Keagamaan Dalam Rehabilitasi Pecandu Narkoba

hidupnya secara sehat baik psikis, fisik, mental, spiritual dan sosial serta dapat mencegah terjadinya relapse pada diri pecandu narkoba. Sehingga dapat hidup bahagia dunia dan akhirat.

Bersumber dari hasil penyelidikan dan pengkajian terhadap karya-karya ilmiah sebelumnya, peneliti menjumpai beberapa karya ilmiah terdahulu yang masih memiliki adanya keterkaitan atau hubungan dengan penelitian ini. Meskipun masih ditemukan beberapa kesamaan dan keterkaitan dalam pembahasan, akan tetapi penelitian ini masih memiliki suatu hal yang menjadi pembeda dengan penelitian sebelumnya. Berikut beberapa hasil penulusuran terhadap penelitian terdahulu, yaitu: Arum Dwi Prihatiningtiyas, 2017, Rehabilitasi Pecandu Narkoba dengan Pendekatan Nilai karakter Religius di Panti Rehabilitasi Narkoba Nurul Ichsan Al-Islami Karangsari, Kecamatan Kalimanah, Kabupaten Purbalingga; Abdul Jabar, 2016, Pengaruh Pendidikan Agama Islam Terhadap Pengguna Narkoba Di Yayasan Rehabilitasi Narkoba ArRahman Plaju Palembang; Mohammad Akbar Awaludin, 2019, Implementasi Bimbingan Keagamaan Sebagai Upaya Pemulihan Kesehatan Mental Bagi Pecandu Narkoba di Yayasan Nurul Ichsan AlIslami Kalimanah Purbalingga; Rafica Lela Zukhruf, 2017, Rehabilitasi Penyalahguna Narkoba Di Panti Nurul Ichsan Al-Islami Desa Karangsari Kecamatan Kalimanah Kabupaten Purbalingga

Dari pernyataan diatas terdapat beberapa fokus penelitian, antara lain: a. Bagaimana proses bimbingan keagamaan dalam rehabilitasi pecandu narkoba di Panti Rehabilitasi Narkoba Nurul Ichsan Al- Islami?, b. Apa saja faktor pendorong dan penghambat dalam proses bimbingan keagamaan bagi para pecandu narkoba di Panti Rehabilitasi Narkoba Nurul Ichsan Al- Islami?, c. Bagaimana hasil dari proses bimbingan keagamaan dalam rehabilitasi pecandu narkoba di Panti Rehabilitasi Narkoba Nurul Ichsan Al- Islami?

Lokasi yang akan dijadikan tempat penelitian ini adalah Panti Rehabilitasi Narkoba Nurul Ichsan Al-Islami, Jl. Pangeran Jangkung, RT 04/ RW 02, Dusun 2 Karangsari, Kecamatan Kalimanah, Kabupaten Purbalingga, 
Lutfia U. Witrin NJ

Jawa Tengah. Metode yang digunakan dalam penelitian ini adalah metode deskriptif kualitatif dengan teknik pengumpulan datanya melalui observasi, wawancara dan dokumentasi, dikarenakan masalah yang diteliti perlu dijelaskan secara sistematis dan faktual dengan menggambarkan fenomena atau keadaan tempat penelitian.

\section{LANDASAN TEORITIS}

Pecandu narkoba adalah orang yang menggunakan narkoba dengan tujuan tidak untuk pengobatan, akan tetapi dengan tujuan ingin menikmati pengaruhnya, digunakan dalam dosis yang berlebih, tidak sesuai dengan aturan dan berlangsung dalam kurun waktu yang lama, sehingga menyebabkan gangguan terhadap kesehatan, fisik, mental, dan kehidupan sosialnya. Jika hal ini dibiarkan dan tidak segera mendapatkan penanganan oleh seorang yang ahli, maka dampak yang ditimbulkan bukan hanya akan dirasakan oleh dirinya sendiri akan tetapi orang dan lingkungan sekitarnya pun akan ikut terdampak negatif. Walaupun demikian, ada pilihan alternatif yang dapat dijadikan solusi dalam upaya penanganan dan pemulihan korban penyalahgunaan narkoba yaitu salah satunya melalui program rehabilitasi, baik rehabilitasi medis maupun non medis. Akan tetapi, dalam penelitian ini peneliti lebih memfokuskan pada program pemulihan atau rehabilitasi narkoba non medis atau terapi herbal yang dipadukan dengan metode bimbingan keagamaan yaitu di Panti Rehabilitasi Narkoba Nurul Ichsan Al-Islami Purbalingga.

Adapun rangkaian pelaksanaan program rehabilitasi narkoba di Panti Rehabilitasi Narkoba Nurul Ichsan Al-Islami Purbalingga secara garis besar terbagi menjadi tiga tahapan, yaitu tahapan pra rehabilitasi; tahapan pelaksanaan rehabilitasi; dan tahapan pasca rehabilitasi. Dalam proses rehabilitasi, pihak panti melarang keras atau menghimbau dengan tegas agar tidak ada zat kimia atau obat-obatan berbahaya yang masuk ke dalam tubuh pecandu narkoba. Sehingga pecandu akan benar-benar merasakan putus zat.

Sedangkan untuk penanganan keadaan sakaw atau relapse yang kerap kali 
dialami pecandu pada saat proses rehabilitasi narkoba adalah dengan menggunakan terapi herbal. Ramuan herbal ini diracik dengan bahan yang terdiri dari rempah-rempah pilihan dan dilengkapi dengan do'a dari Ustadz Ichsan. Berkaitan dengan racun yang terlanjur masuk kedalam tubuh pecandu, dalam proses rehabilitasinya untuk mendetoks racun atau zat kimia atau obat-obatan berbahaya tersebut Panti Rehabilitasi Nurul Ichsan Al-Islami menggunakan metode terapi godok sebagai upaya penanganan. Terapi godok atau terapi rebus merupakan terapi yang digunakan dengan tujuan untuk mendetoks racun atau zat kimia atau obat-obatan berbahaya dalam tubuh pecandu dengan cara tubuh pecandu masuk kedalam tungku yang berisi air mendidih diatas api yang membara yang telah dicampur dengan rempah-rempah dan do'a yang hanya dapat dilakukan serta dibuat oleh Ustadz Ichsan.

Selain terapi herbal dan terapi godok, Panti Rehabilitasi Nurul Ichsan AlIslami juga menggunakan terapi religi atau disebut dengan istilah bimbingan keagamaan. Tujuan adanya bimbingan keagamaan dalam proses rehabilitasi adalah untuk meningkatkan kontrol diri dan memberikan pondasi atau pedoman yang nantinya akan menjadi prinsip hidup yang kuat bagi pecandu supaya dapat hidup sesuai norma agama dan sosial. Sehingga diharapkan tidak mudah untuk kembali terjerumus atau sederhananya untuk mencegah relapse atau kekambuhan pada pecandu.

Hal ini sesuai dengan pendapat Prayitno, yang menyatakan bahwa unsurunsur agama tidak boleh untuk diabaikan dalam proses pelaksanaan bimbingan dan konseling serta harus dimanfaatkan semaksimal mungkin dengan tujuan untuk mencapai kesuksesan proses bimbingan dan konseling dengan memberi kebahagiaan dan harapan baru bagi klien atau santri. Karena dengan adanya peranan agama dalam proses bimbingan dan rehabilitasi akan memberi cerita, arah, dan suasana yang lebih akrab antara santri atau klien dengan konselor.

Dalam proses pelaksanaan bimbingan keagamaan agar dapat berjalan secara maksimal maka sangat dibutuhkan adanya program dan 
Lutfia U. Witrin NJ

perencanaan; pengorganisasian, pelaksanaan, pengawasan dan evaluasi yang baik dengan tujuan agar klien atau santri mendapatkan pola kehidupan yang sehat dan sesuai dengan norma agama dan sosial. Selain itu bimbingan keagamaan dalam prosesnya akan melibatkan beberapa unsur-unsur penting yang harus dipenuhi, antara lain: adanya mursyid atau pembimbing keagamaan; adanya materi bimbingan; adanya metode dalam bimbingan; adanya mursyad bih atau klien dalam bimbingan; adanya tujuan yang ingin dicapai. (Ahmad Subandi dan Sukriadi Sambas, 1999: 54)

Menurut Gunarsa inti dari bimbingan jika dilihat dari sudut pandang psikologis, maka bimbingan memiliki pengertian upaya pemberian bantuan dan arahan kepada klien dalam menyelesaikan masalah yang dihadapinya. Dalam proses bimbingan ada beberapa hal dari pelaksanaan bimbingan keagamaan yang dapat disimpulkan sebagai pokok atau inti, antara lain: dalam bimbingan memiliki tujuan untuk membantu individu ataupun kelompok dalam upaya memberikan arahan untuk menentukan pilihan atau tindakan yang bisa menjadi jalan keluar; dalam pelaksanaan bimbingan keagamaan ada proses belajar bagi klien; hasil dari adanya pelaksanaan bimbingan keagamaan adalah terjadi perubahan perilaku dan perkembangan kepribadian sebagai suatu goals yang ingin dicapai. (Ahmad Subandi dan Syukriadi Sambas, 1999: 56)

Karena Agama Islam bukan agama yang hanya mengajarkan tentang teoritik (ilmu) tapi juga tentang praktik (amal) yang mengaplikasikan dari teoritik tersebut, sehingga membentuk manusia yang tinggi ilmunya dan luas amalnya serta menjadi pribadi yang tangguh dan disegani. Karna apabila manusia hanya dipenuhi dengan ilmunya, hasilnya akan kehilangan keseimbangan dalam hidup serta hilang kepercayaan diri. Seorang sufi Syekh Ahmad Shohibul Wafa Tajul 'Arifin yang tinggi ilmunya dan luas amalnya mengatakan "ilmu amaliah, amal ilmiah". (Opik Jamaludin, 2021: 88)

Atas dasar permasalahan diatas salah satu teori yang relevan atau sesuai adalah teori REBT atau Rational Emotive Behavior Therapy. Teori ini 
didirikan oleh Albert Ellis. Inti dari teori ini adalah memberikan penekanan terhadap hubungan antara kognisi, emosi dan tingkah laku. Yang ketiganya saling berkaitan dan memengaruhi satu sama lainnya. Gagasan ini diperkuat lagi oleh penyataan W.S. Wingkel dalam bukunya yang berjudul Bimbingan dan Konseling Pendidikan, beliau menyatakan: "Suatu perubahan yang mendalam dalam cara berpikir dapat mengakibatkan perubahan yang berarti dalam cara berperasaan dan berperilaku."

Kemudian Epictetus dan Marcus dalam bukunya The Enchiridion memperkuat lagi dengan menyatakan bahwa: "Manusia tidak terlalu banyak dipengaruhi oleh sesuatu yang terjadi pada dirinya. Akan tetapi, manusia lebih dipengaruhi oleh sudut pandangnya, seperti bagaimana manusia memandang atau menafsirkan sesuatu yang terjadi pada dirinya"

Pendapat ini sesuai dengan tujuan dari adanya pelaksanaan bimbingan keagamaan dalam rehabilitasi narkoba yaitu bagaimana caranya agar dapat mengubah cara pandang atau mindset klien atau santri terhadap sesuatu yang terjadi pada dirinya, penerimaan pada kehidupan masa lalu dan mindset positif dapat masuk dalam pola pikir klien atau santri sehingga klien atau santri dapat berpikir dan berperilaku lebih rasional.

Secara global, pandangan teori Rational Emotive Behaviour Therapy ini memfokuskan pada cara berpikir manusia yang dijadikan patokan oleh para konselor atau pembimbing dalam mengubah tingkah lakunya. Sedangkan tujuan secara umum yang ingin dicapai adalah membantu individu untuk berpikir lebih rasional dan produktif, mengurangi emosi yang tidak stabil serta memperbaiki kesalahan dalam berpikir dan berperilaku yang dapat merusak diri, orang lain dan lingkungan sekitar. (Komalasari, 2011)

\section{HASIL DAN PEMBAHASAN}

Yayasan Pendidikan Islami Nurul Ichsan Al-Islami merupakan organisasi sosial yang mulai berkiprah dan berperan dalam upaya pemulihan korban 
Lutfia U. Witrin NJ

penyalahguna narkoba sejak tahun 2000. Kemudian disahkan pada tanggal 17 Januari 2007 dengan akta notaris Agung Diharto, SH dengan nomor Akte 04/ 2007 dan dengan SIOP: 802/ ORSOS/ V 2008. Tidak lama dari itu, tepatnya pada tahun 2013 oleh Menteri Sosial (Mensos) Republik Indonesia dijadikan Institusi Penerima Wajib Lapor (IPWL) dengan SK Mensos Nomor. 36/ HUK/ 2013 tanggal 17 April 2013. Dalam kinerjanya, panti rehabilitasi narkoba ini berperan dan menangani di beberapa bidang, antara lain yaitu: bidang pendidikan agama islam dibuktikan dengan didirikannya pondok pesantren, dalam bidang kemanusiaan terbukti dengan kegiatan sosial yang sering diadakan oleh pihak panti rehabilitasi baik berupa kegiatan santunan anak yatim, duafa dan para janda serta masyarakat dengan tingkat perekonomian menengah ke bawah dan dalam bidang rehabsosial yang telah banyak membantu korban penyalahguna narkoba dalam melewati proses pemulihan.

\section{Proses Bimbingan Keagamaan dalam Rehabilitasi Pecandu Narkoba di Panti Rehabilitasi Narkoba Nurul Ichsan Al- Islami}

\section{Program dan Perencanaan}

a) Program rehabilitasi yang dilaksanakan di Panti Rehabilitasi Narkoba Nurul Ichsan Al-Islami Purbalingga merupakan serangkaian upaya dalam proses pemulihan terhadap para penyalahguna narkoba yang telah dikoordinasikan secara sistematis dan melalui perencanaan yang matang, terdiri dari upaya dalam pemulihan fisik; upaya psikososial; upaya pembinaan mental spiritual; dan upaya dalam pelatihan life skill. Yang memiliki tujuan untuk meningkatkan kemampuan dalam beradaptasi dan melatih rasa kemandirian agar mampu menolong diri sendiri serta dapat memanfaatkan potensi yang dimiliki secara optimal, baik dari segi fisik, psikis, ekonomi, dan sosial.

b) Setiap kegiatan dengan tujuan apapun agar berjalan secara efektif dan efisien maka, semuanya harus dipersiapkan dan direncanakan terlebih dahulu secara matang. Demikian pula, layanan bimbingan keagamaan akan berjalan dengan efektif dan efisien jika sebelumnya sudah dipersiapkan dan direncanakan secara matang dalam menentukan apa yang akan dilaksanakan, akan dilaksankan dimana, akan dilakukan 
dimana, bagaimana melakukannya, dan siapa yang akan melakukannya. Adapun dalam upaya pencapaian tujuan itu membutuhkan proses manajemen yang sehat, dalam arti terarah, efektif dan efisien.

Berdasarkan jawaban dari Ustadz Ichsan dalam proses wawancara, beliau menyebutkan bahwasannya hal-hal yang perlu dicermati terkait proses perencanaan program bimbingan keagamaan adalah seorang pembimbing harus memiliki kemampuan untuk mengatur, menjalankan, mengevaluasi, menyelidiki dan menindaklanjuti terhadap bimbingan keagamaan yang dilaksanakan. Melalui perencanaan yang terstruktur dengan baik, diharapkan program atau kegiatan yang akan dilaksanakan menjadi lebih terarah dan sistematis. (Wawancara Ustadz Ichsan Maulana, 18 Juni 2021)

\section{Pengorganisasian}

Dalam sebuah wawancara, Ustadz Ichsan menjelaskan tentang arti penting dari adanya pengorganisasian dalam sebuah bimbingan keagamaan, beliau berkata bahwa pengorganisasian memiliki arti penting dalam proses pelaksanaan bimbingan keagamaan, karena dengan adanya pengorganisasian nantinya kegiatan bimbingan keagamaan lebih mudah untuk dibagi dalam tugas-tugas yang lebih rinci kepada setiap pelaksana kegiatan, sehingga akan terhindar dari adanya penumpukkan tugas yang biasanya dibebankan pada satu atau dua orang saja. (Wawancara Ustadz Ichsan Maulana, 18 Juni 2021)

Pengorganisasian yang baik ditandai oleh adanya dasar dan tujuan dalam sebuah kegiatan, memiliki administratif yang jelas dan tegas, personel yang matang dan memiliki pemahaman akan tanggung jawab, tugas dan wewenangnya serta perannya dalam menciptakan hubungan kerja yang harmonis. Pengorganisasian kegiatan bimbingan keagamaan memiliki peran kunci dalam menunjang keberhasilan pelaksanaan program bimbingan keagamaan. Hal ini dikarenakan dengan adanya pembagian tugas yang jelas dalam pengorganisasian akan memberikan pedoman dan arah bagi setiap pelaksana bimbingan keagamaan.

Dengan demikian dapat disimpulkan, jika pengorganisasian dalam bimbingan keagamaan bukan semata-mata proses penyusunan atau 
pengelompokkan saja. Melainkan, lebih menekankan pada bagaimana sebuah kegiatan yang dilakukan bisa berjalan secara terstruktur atau tersusun dengan rapi. Karena, pengorganisasian disini lebih menekankan pada pengaturan mekanisme kerja personel pelaksana bimbingan keagamaan.

\section{Pelaksanaan}

Dalam pelaksanaan bimbingan keagamaan di Panti Rehabilitasi Nurul Ichsan Al-Islami dilakukan secara rutin setiap harinya. Dalam prosesnya bukan hanya pembimbing yang menjadi pelaksana, akan tetapi para santri juga dilatih untuk berani menjadi pelaksana bimbingan. Hal ini, dilakukan agar nanti saat santri kembali ke masyarakat dapat bermanfaat dan dapat mematahkan stigma buruk masyarakat tentang dirinya. Hal ini disampaikan oleh Ustadz Ichsan, beliau mengatakan bahwasannya klien atau santri dalam proses rehabilitasi dilatih untuk menjadi seorang muadzin, belajar menjadi seorang imam sholat 5 waktu, bahkan mereka juga dilatih untuk mampu berbicara didepan umum. Dan semuanya dilakukan secara bergantian. Dengan bekal materi yang telah diberikan oleh Ustadz Ichsan. Sehingga, kegiatan keagamaan ini menjadi kegiatan pokok yang wajib diikuti oleh para klien atau santri. Jika ada yang tidak ikut tanpa ada alasan yang jelas, maka akan mendapatkan sanksi." (Wawancara Ustadz Ichsan Maulana, 18 Juni 2021)

Dalam proses pelaksanaan bimbingan keagamaan ada tujuan khusus yang ingin dicapai, yaitu adanya perubahan sikap kearah yang lebih baik lagi sehingga akan membentuk akhlakul karimah. Bimbingan keagamaan dalam proses rehabilitasi merupakan salah satu bentuk pelaksanaan rehabilitasi yang dimodifikasi dengan nilai-nilai agama yang bertujuan merubah mindset-nya sehingga akan berdampak pada perbaikan sikap dan kebiasaannya. Selain itu juga, dengan mengikuti pelaksanaan bimbingan keagamaan akan memberikan perasaan tenang dan damai ketika dekat dengan Alloh dengan melaksanakan segala perintah-Nya dan meninggalkan segala yang dilarang-Nya.

Adapun beberapa metode yang dapat dilakukan pada saat pelaksanaan bimbingan keagamaan antara lain, yaitu: 


\section{a) Metode herbal}

Metode pengobatan herbal yaitu metode yang digunakan untuk memulihkan kondisi para pasien yang mengalami kecanduan terhadap narkoba dengan upaya memberikan ramuan herbal seperti air kelapa, kunyit, kapulaga, daun sirih wulung, kurma ajwa dan madu arab. Ramuan ini diolah menjadi jamu tradisional yang memiliki khasiat untuk mengobati pasien yang mengalami sakau atau kecanduan.

\section{b) Metode Godok Atau Rebus}

Metode terapi godok atau rebus yaitu metode pengobatan dengan cara merebus tubuh pasien pecandu narkoba ke dalam tungku atau gentong yang berukuran besar dengan diameter $57 \mathrm{~cm}$ dan tinggi $160 \mathrm{~cm}$. Tungku atau gentong tersebut berisi air yang direbus di atas api yang membara dan diberi ramuan yang komposisinya antara lain daun jambu biji, daun salam, daun kamijara, ragi dan satu ember air yang diberi doa oleh Ustadz Ichsan.

Kemudian pasien akan masuk kedalam gentong dengan posisi duduk hingga air mencapai sebatas dada pasien. Sebelum masuk kedalam tungku, pasien akan mengucap akad terlebih dahulu dengan ustadz Ichsan lalu kemudian dibacakan doa oleh Ustadz sambil berjabat tangan. Setelah itu pasien baru bisa masuk ke dalam gentong. Waktu yang digunakan pada saat proses penggodokan dibutuhkan sekitar 10 sampai 25 menit, dilakukan pada setiap malam Minggu. Setelah proses perebusan atau penggodokan pasien dilarang mandi biasa. Hal ini, bertujuan untuk mendetoks racun yang ada didalam tubuh pasien yang disebabkan pemakaian narkoba, sehingga racun tersebut dapat keluar melalui poripori berupa keringat yang berwarna. Keringat dengan warna merah pada tubuh pasien menandakan bahwa pasien pengguna ganja dan keringat berwarna putih pada tubuh pasien menandakan pasien pengguna sabu dan heroin atau sejenisnya.

\section{c) Metode Mandi Malam}

Metode mandi malam adalah salah satu bentuk terapi yang menjadi pengobatan dalam upaya memulihkan kembali kondisi psikis dan fisik 
Lutfia U. Witrin NJ

dengan cara mengajak pasien atau mantan pecandu narkoba untuk melakukan ritual mandi malam di sungai yang menjadi poros pertemuan tiga aliran sungai, yaitu Sungai Klawing, Sungai Kaligintung dan Sungai Kalibanjaran di Purbalingga. Metode mandi malam ini biasanya dilakukan pada saat tengah malam. Dan dilakukan khusus pada hari Jum'at Kliwon dan hari-hari yang memiliki pasaran Kliwon. Tujuannya adalah untuk mendapatkan reaksi dingin yang memberi ruang dalam otak agar asupan oksigen dapat mudah masuk sehingga pikiran akan lebih segar dan tenang.

\section{d) Metode Terapi Lingkungan}

Yaitu metode pengobatan dengan cara pasien diajak ke tempat-tempat rekreasi wisata sebagai tadabur alam. Hal ini sebagai sarana dalam menggali ilmu dan melatih diri untuk lebih dekat kepada Alloh sehingga dapat menambah kecintaan kepada Alloh dan selalu ada keinginan untuk mengenal lebih dalam lagi tentang keberadaan dan kekuasaan Alloh.

Melalui terapi lingkungan dalam proses rehabilitasi berfungsi dalam upaya memurnikan secara lahir dan batin klien atau santri dari dorongandorongan kurang baik yang mungkin telah mengakar di hati dan pikiran klien. Selain itu dengan tadabur alam maka akan menambah rasa syukur klien atas karunia Alloh.

\section{e) Metode Religi (Bimbingan Keagamaan)}

Metode religi atau bimbingan keagamaan adalah metode yang dilakukan dengan menggunakan pendekatan keagamaan. Metode jenis ini diterapkan dengan menggunakan pendekatan-pendekatan pada ayatayat suci Al-Qur'an dan Hadits Nabi. Dalam pelaksanaan bimbingan keagamaan yang dilakukan di Panti Rehabilitasi Narkoba Nurul Ichsan Al-Islami, pembimbing biasanya menggunakan metode religi ini melalui: kegiatan membaca Al-Qur'an, sholat 5 waktu dan sunnah, berdzikir kepada Alloh, berdo'a dan kajian kitab safinah dalam memahami fiqh dalam beribadah dan bermuamalah. Metode religi atau bimbingan keagamaan berguna untuk membantu klien dalam memahami diri sendiri, mengetahui sumber kesulitan atau penyakit yang dialami, 
Peran Bimbingan Keagamaan Dalam Rehabilitasi Pecandu Narkoba

membantu klien dalam menentukan langkah-langkah untuk meningkatkan motivasi diri, dan mengingatkan klien jika pada akhirnya semua akan kembali kepada Alloh.

Untuk mewujudkan tujuan diatas, maka dibutuhkan persiapan materi yang matang. Materi disini merupakan bahan dasar berupa konsep untuk disampaikan kepada klien, baik berupa ilmu pengetahuan, ilmu agama, motivasi, nasehat dan lain sebagainya pada saat proses bimbingan keagamaan dilakukan. Berikut materi yang biasa disampaikan pembimbing keagamaan kepada klien atau santri pada saat proses bimbingan keagamaan, yaitu:

\section{a) Masalah Aqidah (Keimanan)}

Materi ini disampaikan kepada santri dengan tujuan supaya jiwanya tertanam rasa keimanan kepada Alloh. Dengan iman yang kokoh dan kuat maka santri tidak akan melakukan berbagai kejahatan dan kemungkaran serta mencegah relapse. Dan akan memberi kesadaran terhadap diri santri bahwa perilaku dan perbuatan di masa lalu merupakan kesalahan yang telah melanggar norma agama dan sosial.

Adapun materi mengenai keimanan atau aqidah ini adalah mengenai ajaran pokok Islam yang berkaitan dengan keyakinan atau keimanan. Dan materi ini terangkum dalam rukun iman, yaitu 1) iman kepada Alloh; 2) iman kepada malaikat; 3) iman kepad kitab-kitab suci; 4) iman kepada Rasul Alloh; 5) iman kepada hari akhir; 6) iman kepada qada dan qadar. (Wawancara Ustadz Ichsan Maulana, 18 Juni 2021)

\section{b) Masalah Syari'ah}

Materi yang berhubungan dengan masalah syariah adalah materi yang mengatur dan membahas mengenai amalan yang dapat dilihat secara dzohir, baik amalan dalam beribadah maupun bermuamalat yang berpedoman pada aturan dan hukum Alloh yang bersumber pada AlQuran dan As-Sunnah dalam upaya mengatur kehidupan manusia, baik kehidupan yang hubungannya dengan Alloh, hubungannya dengan makhluk maupun hubungan dengan lingkungan agar tatanan kehidupan menjadi seimbang, selaras, harmonis dan damai. 
Lutfia U. Witrin NJ

\section{c) Masalah Budi Pekerti (Akhlakul Karimah)}

Budi pekerti merupakan segala sesuatu yang berhubungan erat dengan karakter manusia, baik dari sisi sifat atau perangai maupun perilaku atau tindakan yang semuanya dilakukan dalam keadaan sadar dan penuh kesadaran. Perbuatan ini dapat dilihat dari niat yang terealisasikan dalam tindakan ataupun peilaku dalam kehidupan sehari-hari. Bagaimana akhlak yang baik dan tata cara dalam memperlakukan atau bersikap kepada orang yang lebih tua, orang yang sebaya, bahkan sikap kepada orang yang lebih muda. Semua telah diatur dalam norma agama dan sosial. Jadi jika dilanggar akan mendapat dosa, sanksi sosial bahkan sanksi hukum. Materi akhlakul karimah antara lain mencakup materi untuk berbakti kepada orang tua, saling hormat-menghormati, tolong menolong dan lain sebagainya. (Syukir, 1983:60-62)

\section{Pengawasan}

Pengawasan dalam proses bimbingan keagamaan merupakan pengamatan yang bertujuan untuk mengawasi pelaksanaan programprogram yang ada didalam kegiatan bimbingan keagamaan. Baik proses kegiatan dari awal sampai hasil akhir dari adanya klien mengikuti bimbingan keagamaan. Maka, nantinya akan diperoleh data yang berkesinambungan dan valid untuk dijadikan dasar dalam proses evaluasi dan perbaikan. Pengawasan yang dilakukan di panti rehabilitasi dilakukan dengan cara pendampingan oleh pembimbing dalam setiap kegiatan keagamaan dilakukan. Dalam proses bimbingan keagamaan sangat dibutuhkan adanya pengawasan. Hal ini bertujuan agar adanya kemajuan dan meningkatkan kualitas pelaksanaan bimbingan keagamaan. Maka peran pembimbing sebagai pengawas juga sangat dibutuhkan.

\section{Evaluasi}

Dalam keseluruhan kegiatan keagamaan, evaluasi diperlukan untuk memperoleh umpan balik terhadap keefektifan pelaksanaan bimbingan keagamaan. Dengan data seperti ini maka, informasi mengenai kefektifan layanan bimbingan keagamaan dapat dilihat hasilnya. Dan tahapan 
Peran Bimbingan Keagamaan Dalam Rehabilitasi Pecandu Narkoba evaluasi berfungsi dalam usaha pembaharuan-pembaharuan terhadap program-program dan pelayanan dalam upaya meningkatkan dan mengembangkan kualitas kearah yang lebih baik lagi.

Faktor Pendorong dan Penghambat dalam Proses Pelaksanaan Bimbingan Keagamaan bagi Para Pecandu Narkoba di Panti Rehabilitasi Narkoba Nurul Ichsan Al- Islami

\section{Faktor Pendorong Bimbingan Keagamaan}

a) Adanya kemauan, tekad yang besar dan sungguh-sungguh dari dalam hati dan diri pecandu narkoba untuk serius dan ingin belajar ilmu agama Islam dengan tekun. Dengan demikian akan tercipta kesadaran dalam diri pecandu narkoba untuk berubah menjadi pribadi yang lebih baik lagi dengan tekad yang bulat dan prinsip yang kuat untuk tidak melakukan hal-hal yang dilarang oleh agama.

b) Adanya dukungan atau motivasi dari orang tua. Karena, dukungan orang tua memiliki peran yang penting dalam proses bimbingan keagamaan. Dengan adanya dukungan dari orang tua akan menambah semangat pecandu dalam proses belajar ilmu agama untuk perubahan kearah yang lebih positif. Selain itu juga orang tua bisa mengawasi dan mengetahui perkembangan anaknya seperti apa

c) Dari segi fasilitas dalam proses pelaksanaan bimbingan keagamaan memiliki peran yang penting juga. Karena dengan adanya fasilitas yang memadai akan memberi manfaat dan kemudahan yang berarti bagi keberhasilan proses bimbingan keagamaan. Pemanfaatan fasilitas dapat mempermudah pembimbing ataupun petugas dalam menyampaikan materi baik berupa ilmu pengetahuan, nasehat, motivasi dan lain sebagainya yang disampaikan, sehingga pecandu akan mendapat hasil belajar yang optimal.

Faktor Penghambat Bimbingan Keagamaan

a) Kurangnya tenaga pembimbing yang ahli dan berkompeten dalam bidang agama. Sehingga menghambat dan mempersulit proses bimbingan keagamaan terhadap klien karena hanya mengandalkan atau bertumpu pada satu orang pembimbing. Dengan demikian kegiatan 
Lutfia U. Witrin NJ

bimbingan keagamaan tidak berjalan secara maksimal.

b) Kurang adanya kemauan dari dalam hati dan diri pecandu narkoba sehingga hal ini akan mempersulit dirinya dalam mengikuti proses bimbingan keagamaan. Karena belum adanya kesadaran dalam diri pecandu narkoba akan pentingnya mengikuti bimbingan keagamaan. Sehingga menghambat dalam proses perkembangan dan peningkatan kualitas diri kearah yang lebih baik.

c) Kurang adanya dukungan atau motivasi dari orang tua juga menjadi salah satu faktor yang menghambat dalam proses pelaksanaan bimbingan keagamaan. Karena pecandu narkoba butuh diakui dan butuh perhatian dari orang tua. Dengan dua hal tersebut yang tidak terpenuhi oleh orang tua memberikan dampak buruk bagi klien. Hal ini dapat dilihat dari hasil yang menunjukan perubahan yang lebih lambat dari klien atau santri lainnya.

\section{Hasil dari Pelaksanaan Bimbingan Keagamaan terhadap Pecandu Narkoba dalam Proses Rehabilitasi Narkoba di Panti Rehabilitasi Narkoba Nurul Ichsan Al- Islami}

Mengenai output atau hasil dari pelaksanaan bimbingan keagamaan di Panti Rehabilitasi Narkoba Nurul Ichsan Al-Islami, berdasarkan data dari hasil wawancara dengan beberapa klien, didapatkan output atau hasil dari adanya bimbingan keagamaan dalam rehabilitasi narkoba, yaitu:

a) Mendapatkan ketenangan yang hakiki. Jika dilihat narkoba seperti dua sisi mata uang. Di satu sisi menjadi zat yang memberikan manfaat, akan tetapi di sisi lain juga dapat merusak kesehatan. Seperti halnya, ada beberapa obat-obatan yang berasal dari jenis narkoba yang digunakan dalam proses penyembuhan karena kandungan efek yang memberikan ketenangan pada pasien. Namun, jika digunakan dengan dosis yang berlebih dapat menyebabkan kecanduan. Banyak orang yang tergiur dengan efek yang diberikan oleh narkoba yaitu si pengguna akan merasakan efek yang menyenangkan sehingga timbul dorongan untuk terus menggunakan agar mendapatkan ketenangan meskipun hanya bersifat halusinasi. 
Dengan adanya bimbingan keagamaan dalam rehabilitasi narkoba akan memberikan kesadaran pada diri klien tentang hakikat ketenangan yang sesungguhnya hanyalah dengan cara mendekatkan diri dan kembali kepada Alloh dengan taubat nasuha.

Alloh Subhanahu Wa Ta'ala berfirman:

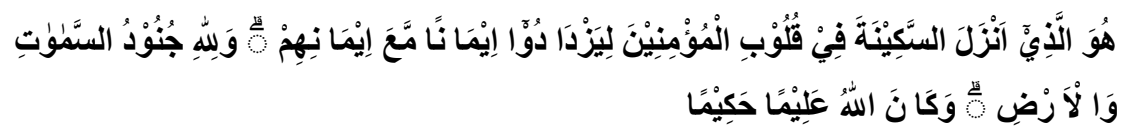

Artinya:

"Dialah yang telah menurunkan ketenangan ke dalam hati orang-orang mukmin untuk menambah keimanan atas keimanan mereka (yang telah ada). Dan milik Alloh-lah bala tentara langit dan bumi, dan Alloh Maha Mengetahui lagi Maha Bijaksana." (QS. Al-Fath 48: 4)

Pada setiap orang yang beriman dan bertaqwa kepada Alloh SWT memiliki keyakinan yang kuat jika sumber ketenangan jiwa dan hati adalah dengan menjalankan perintah-Nya dan menjauhi larangan-Nya. Seperti menjalankan sholat 5 waktu, mengaji, berdoa dan berbuat baik kepada orang tua. Dan dalam proses rehabilitasi, klien atau santri akan dibimbing dan dibina untuk kembali kepada jalan yang benar dan jalan yang diridhoi oleh Alloh.

Setelah mengikuti proses bimbingan keagamaan, kebanyakan klien atau santri mengaku mendapatkan ketenangan yang sebelumnya belum pernah mereka rasakan. Karena mereka mengaku sebelumnya hanya mendapatkan ketenangan sementara, selepas efek yang diberikan narkoba hilang dan mereka kembali sadar, mereka akan merasakan keresahan dan kepayahan dalam masalah hidup yang dihadapi. Hal ini menunjukkan bahwa ada sebuah ketenangan yang tidak bisa dirasakan oleh semua orang, kecuali mereka yang senantiasa menjadika Alloh SWT sebagai sandaran hatinya.

b) Adanya perubahan mindset atau pola pikir. Salah satu bukti keberhasilan dari adanya pelaksanaan bimbingan keagamaan dalam rehabilitasi narkoba adalah adanya perubahan mindset atau pola pikir pada diri klien atau santri. Hal ini disebabkan karena pola pikir 
Lutfia U. Witrin NJ

merupakan dasar atau fondasi bagi seluruh tindakan pada diri manusia. Apapun alasan yang melatarbelakangi pada setiap keputusan yang manusia buat semua diatur dan dipengaruhi bahkan didikte oleh kinerja mindset atau pola pikir yang terbentuk dalam diri manusia. Ada dua arah perubahan pada pola pikir manusia, yaitu perubahan menuju arah yang baik atau sebaliknya. Melalui proses bimbingan keagamaan klien atau santri akan dibawa dan di doktrin dengan mindset positif sehingga ada perubahan pada ucapan, perilaku bahkan kebiasaan yang lebih baik dari sebelumnya.

Salah satu faktor penting dalam pembentukan pola pikir adalah adanya informasi positif yang masuk, baik berupa nasihat dari ayah ibu atau orang tua, ustadz atau kiyai, guru disekolah maupun dari teman. Bukan hanya itu melalui kegiatan bimbingan keagamaan seperti mengaji, mengerjakan sholat, mendengarkan ceramah, berdo'a itu juga memberi pengaruh kuat pada perubahan pada arah yang lebih positif. Seperti pengakuan beberapa klien dari hasil wawancara langsung, mereka mengaku kegiatan keagamaan tidak pernah lagi ditinggalkan, semangat dalam belajar kian meningkat dan tumbuhnya gairah dalam memperbaiki diri kearah yang lebih baik lagi, menjadi lebih percaya diri dan semangat untuk beribadah juga meningkat dari sebelum mengikuti kegiatan bimbingan keagamaan.

c) Adanya perubahan perilaku. Melalui bimbingan keagamaan ada proses belajar yang terjadi pada diri klien atau santri. Dari adanya proses belajar yang dilakukan klien atau santri akan menghasilkan dampak pada perubahan perilaku. Dan perubahan perilaku ini dapat terlihat dari adanya sikap yang lebih baik, bertambahnya ilmu pengetahuan, dan semakin terasahnya skill atau potensi yang dimiliki oleh klien atau santri. Berdasarkan wawancara dengan para klien, mereka mengaku mengalami hasil yang positif, yang mulanya dari segi beribadah kurang baik atau biasa saja bahkan ada yang mengaku sangat jauh dari ajaran Islam, kini setelah mengikuti kegiatan bimbingan keagamaan, kehidupan spiritual mereka mulai semakin bertambah baik.

\section{PENUTUP}


Berdasarkan data hasil temuan, pembahasan dan analisis terhadap fakta atau data yang dikumpulkan selama penelitian yang mengacu pada rumusan masalah yang telah dikemukakan pada pembahasan sebelumnya, maka peneliti dapat simpulkan bahwa peran bimbingan keagamaan dalam proses rehabilitasi pecandu narkoba di Panti Rehabilitasi Narkoba Nurul Ichsan Al-Islami baik dari segi perencanaan, pengorganisasian, pelaksanaan, pengawasan dan evaluasi telah banyak membantu dan mengarahkan pada pengembangan dan perbaikan perilaku klien atau santri menuju akhlakul karimah.

Faktor pendorong dan faktor penghambat memiliki pengaruh atau dampak yang besar sebagai patokan untuk mengukur keberhasilan dari pelaksanaan bimbingan keagamaan itu sendiri. Agar pecandu narkoba setelah pulih tidak kembali relapse atau kambuh maka antara diri pecandu narkoba, keluarga, pembimbing agama dan fasilitas harus saling mendukung dengan penuh semua kegiatan yang dilaksanakan. Akan tetapi, apabila semua faktor diatas tidak saling mendukung maka dapat menjadi salah satu penghambat keberhasilan dari pelaksanaan bimbingan keagamaan yang dilakukan terhadap klien atau santri.

Mengenai output atau hasil dari pelaksanaan bimbingan keagamaan di Panti Rehabilitasi Narkoba Nurul Ichsan Al-Islami, para klien mengaku mengalami hasil yang positif, diantaranya adalah: mendapatkan ketenangan yang hakiki; adanya perubahan mindset atau pola pikir; dan adanya perubahan perilaku

\section{DAFTAR PUSTAKA}

Anshari, Endang Saifuddin. (2004). Wawasan Islam. Jakarta.: Gema Insani Press.

Awaludin, Mohamad Akbar. (2019). Implementasi Bimbingan Keagamaan Sebagai Upaya Pemulihan Kesehatan Mental Bagi Pecandu Narkoba di Yayasan Nurul Ichsan Al- Islami Kalimanah Purbalingga. Ushuluddin, Adab dan Dakwah. Institut Agama Islam Negeri Pekalongan. 
Lutfia U. Witrin NJ

Dewi, Putri Asmara. (2018). Therapeutic Community Bagi Pecandu Narkoba di Loka Rehabilitasi BNN Kalianda Kabupaten Lampung Selatan. Dakwah dan Ilmu Komunikasi. Universitas Islam Negeri Raden Intan Lampung. Lampung.

Faqih, Aunur Rahim. (2001). Bimbingan dan Konseling dalam Islam. Jogjakarta: UII Press Yogyakarta.

Farida dan Saliyo. (2008). Teknik Bimbingan Konseling Islam. Sekolah Tinggi Agama Islam Negeri Kudus. Kudus.

Jalaludin. (2015). Psikologi Agama: Memahami Tingkah Laku dengan Mengaplikasikan Prinsip-Prinsip Psikologi. Jakarta: Pt Raja Grafindo Persada.

Jamaludin, Opik. (2021). Peran Pesantren Salafi dalam Peningkatan Kualitas Akhlak Santri. Iktisyaf: Jurnal Ilmu Dakwah dan Tasawwuf. Vol. 3. No. 1. Hal. 86-106

Latifah, Nur Khayyu. (2018). Rehabilitasi Mental Spiritual Bagi Pecandu Narkoba Di Pondok Pesantren Jiwa Mustajab Purbalingga (Analisis Bimbingan Dan Konseling Islam). Dakwah dan Komunikasi. Universitas Islam Negeri Walisongo Semarang. Semarang.

Ni'ami, Alifia Nuzilu. (2019). Bimbingan dan Konseling Islam dengan Teknik Self Control bagi Pengguna Narkoba dan Minuman Keras di Dusun Selorentek Kulon Kelurahan Karanganyar Kecamatan Kraton Kabupaten Pasuruan. Dakwah dan Komunikasi. Universitas Islam Negeri Sunan Ampel Surabaya. Surabaya.

Nurihsan, Ahmad Juntika dan Akur Sudiarto. (2009). Manajemen Bimbingan dan Konseling di Sekolah Dasar. Jakarta: Grasindo.

Putri, Intan Agitha. (2018). Hubungan Antara Self Efficacy Dan Kecenderungan Relapse Pada Pecandu Narkoba Yang Menjalani Rehabilitasi. Psikologi dan Ilmu Sosial Budaya. Universitas Islam Indonesia Yogyakarta. Yogyakarta.

Renny, Clauradita Angga. (2018). Terapi Mandi dan Dzikir dalam Upaya Pemulihan Pecandu Narkoba (Studi Kasus Di Pondok Pesantren 
Peran Bimbingan Keagamaan Dalam Rehabilitasi Pecandu Narkoba

Ta'mirul Islam Tegalsari Surakarta). Ushuluddin dan Dakwah. Institut Agama Islam Negeri Surakarta. Surakarta.

Sejati, Dhiya Wisnu. (2015). Terapi Godok Gangguan Jiwa Diagnosa Penyalahgunaan Zat Adiktif di Yayasan Nurul Ichsan Al Islami Purbalingga. Dakwah dan Komunikasi. Insitut Agama Islam Negeri Purwokerto. Purwokerto.

Sulaiman, Ilman. dkk. (2016). Peran Yayasan Pendidikan Islam Nurul Ichsan Al Islami dalam Rehabilitasi Sosial dan Ekonomi Bagi Pecandu Narkoba Melalui Pengobatan Herbal (Non Medis), Pendekatan Spiritual (Islami) dan Program Pemberdayaan. Kontekstualitas. Vol.32. No.2.

Sutirna. (2013). Bimbingan dan Konseling Pendidikan Formal dan Nonformal dan Informal. Yogyakarta: Cv. Andi Offset.

W.J.S. Poerwardaminta. (1976). Kamus Umum Bahasa Indonesia. Jakarta: Balai Pustaka.

Yunita, Feni. (2018). Proses Pemulihan Pengguna Narkoba Melalui Terapi Zikir Dipusat Rehabiilitasi Narkoba Ar- Rahman Palembang. Kesehatan Masyarakat. Universitas Sriwijaya. Sriwijaya.

Zukhruf, Rafica Lela. (2017). Rehabilitasi Penyalahguna Narkoba Di Panti Nurul Ichsan Al-Islami Desa Karangsari Kecamatan Kalimanah Kabupaten Purbalingga. Ilmu Pendidikan. Universitas Negeri Semarang. Semarang. 